総合論文

\title{
新規シルセスキオキサンの
} 合成と触媒機能

Preparation and the Activity of Novel Silsesquioxane-Based Catalysts

Kenji Wada* and Takeaki Mitsudo

Preparation of novel oligosilsesquioxanes-based materials and metal-containing ones as homogeneous and heterogeneous catalysts of excellent activity are reviewed. The authors examined the activity of a $\mathrm{V}$-containing silsesquioxane as a homogeneous catalyst for the photo-oxidation of simple alkanes. For the epoxidation of alkenes catalyzed by Ti-silsesquioxanes, the presence of alkenylsilyl substituents around the Ti center shows significant promotional effects. By utilizing silsesquioxanes bearing appropriate functional groups, novel caged molecules with organic-inorganic hybrid structures were prepared as well as soluble cooligomers, starburst-type polymers, and a dendrimer containing metallasilsesquioxanes. Furthermore, the authors found that these metal-containing silsesquioxanes can be good precursors of oxide catalysts with high BET surface areas and uniformly-controlled pores. Remarkably, the catalysts containing $\mathrm{V}$ and $\mathrm{Al}$ species were found to show excellent activity for photo-assisted aerobic oxidation of methane into methanal and the cracking of cumene, respectively.

Key words: metal-containing silsesquioxanes, organic-inorganic hybrid catalysts, oxidation of alkanes, epoxidation of alkenes, porous oxide catalysts, cracking of hydrocarbons

はじめに

有害物質を使わず作らず，安全かつ経済的な合成プロ セスを可能にする環境対応型不均一系触媒の創製のため には，触媒活性点の原子レベルでの自在制御に加えて， ナノレベルおよびマクロレベルでの反応場の立体構造, 電了構造, 細孔構造, 親溶媒性等が完全に掌握・制御可 能な, 新しい夕イプの触媒材料の創製が久かせない11。 しかし, 従来の不均一系触媒の調製法においては, そう した制御は一般に困難であることが多い。

一方，シルセスキオキサンは，一般式 $\left(\mathrm{RSiO}_{3 / 2}\right)_{\mathrm{n}}$ で表 され，ケイ素上に有機置換基を 1 つ有する有機ケイ素ポ リマーの総称である。一般に有機溶媒に可溶で, 熱的・ 化学的安定性が高く，有機置換基によって物性が容易に 制御できるといった特徵を有している2)。メチル基や フェニル基をはじめとして, 多種多様な有機置換基を含 むポリマーが合成されており，すでに電子材料，レジス 卜, 層間絶縁膜, 光学材料, レジン, ゴム等に広く使わ れている，なじみの梁い素材である。その中でも金属種 を含むかご状シルセスキオキサンは，ゼオライトやシリ

\section{* 京都大学大学院工学研究科}

* Graduate School of Engineering, Kyoto University
力担持触媒といった固体触媒において想定されている活 性点に類似した構造を有しており, 厳密な構造決定およ び制御が容易であることから, 新しい触媒材料として特 に注目されている ${ }^{3)}$ 。筆者らはこのようなかご状シルセ スキオキサンの特徵に着目し, 新規金属含有かご状シル セスキオキサンの合成，および均一系触媒としての機能 開発に加えて，これらを活用した，回収再利用が容易で 環境負荷の少ない有機合成プロセスを可能にする新しい 形態の触媒の開発に取り組んでいる ${ }^{3 \mathrm{~h})}$ 。

本稿では，これまでのシルセスキオキサンを活用した 触媒化学の概要に加え, 筆者らによる種々の形態のシル セスキオキサンの合成，および金属含有シルセスキオキ サンを前駆体として活用した不均一系酸化物触媒の開発 の検討例を紹介する。

\section{1. 金属含有シルセスキオキサンの合成と触媒機能}

シルセスキオキサンは, その有機置換基や前駆体，合 成法の違いによって様々な形態をとり得る。主な構造と してはスキーム1に示したようなランダム構造，ラダー 型構造，かご状構造等が挙げられる ${ }^{2)}$ 。中でもかご状才 リゴマーとして，ヘキサシルセスキオキサン $\left(\mathrm{T}_{6}\right)$ ，才 クタシルセスキオキサン $\left(\mathrm{T}_{8}\right)$ ，デカシルセスキオキサ ン $\left(\mathrm{T}_{10}\right)$ 等の構造が確認されており, 最も一般的なもの は $\mathrm{T}_{8}$ ケージを有するものである。その他にも, より大 
きく複雑なかご状構造をとり得ることが知られている。

さらに，有機置換基や合成条件によっては，不完全に 縮合した，シラノール基を有するかご状オリゴマーを合 成することができる。こうしたオリゴマーは，シリカ表 面との構造の類似性が指摘されており，極めて興味深 い。その代表的な例が不完全縮合へプタマー1aであ $3^{3 \mathrm{a}, 4)}$ 。1a 3 つのお互いに endo 配向したシラノール 基を有するが，その構造は $\beta$-クリストバライトの (111) 面のそれに酷似しており，いわば「シリカ表面の一部を 切り出して有機溶媒に可溶化した」ような分子である。 1965 年に，すでに Brown らがシクロヘキシルトリクロ ロシランの脱水縮合によって，1aが2, 3 とともに合成 できることを報告している4）しかし，合成に極めて長 時間を要することから，これらが構造的に興味深いにも かかわらず，さらなる応用に関する検討は長らく進まな かった。

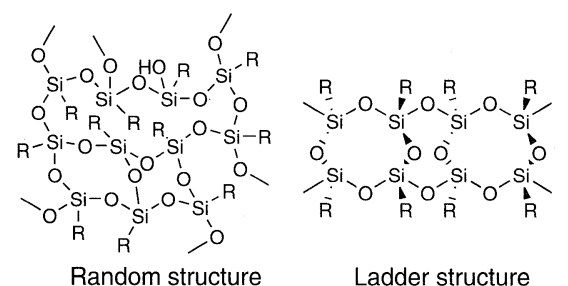

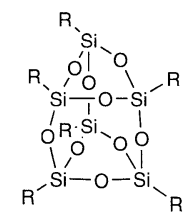

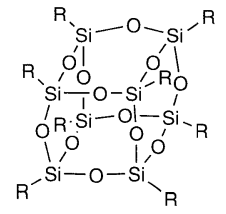

$T_{8}$ cage

Cage structure

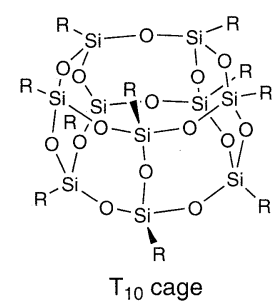

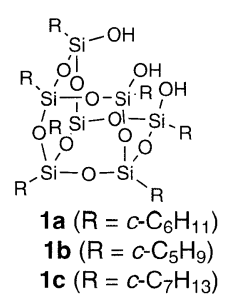

Incompletely-condensed structure

Scheme 1 Structure of silsesquioxanes.

不完全縮合シルセスキオキサンの化学における次なる ブレークスルーは，1986 年にFeherによって報告され た，金属含有かご状シルセスキオキサンの合成であ る5)。塩化メチレン溶媒中, 1a と $\mathrm{Cp} * \mathrm{Zr}\left(\mathrm{CH}_{2} \mathrm{C}_{6} \mathrm{H}_{5}\right)_{3}$ の 反応を室温で行うことによって，コーナーキャップ型の $\mathrm{Zr}$ 含有シルセスキオキサン $4 \mathrm{a}$ が得られ(式 1 )，X 線結 晶解析によって構造が決定された。その後Feher らは， 主として前周期遷移金属種や典型元素を含むかご状シル セスキオキサンを数多く合成するとともに，不完全縮合
ヘプタマーのシクロペンチル誘導体 $1 \mathrm{~b}$ ，およびシクロ ヘプチル誘導体 1c 等の簡便な合成法を開発した(スキー ム 1 $)^{6)}$ 。最近では, 数多くの研究グループがシルセスキ オキサンのかかわる化学に取り組んでおり，種々の金属 種を骨格内に含有する分子が合成されている。こうした 成果の一部はすでにいくつかの優れた総説にまとめられ ている 子 $^{3 \mathrm{c}, \mathrm{d}, \mathrm{f}, \mathrm{g}, \mathrm{h})}$ 。

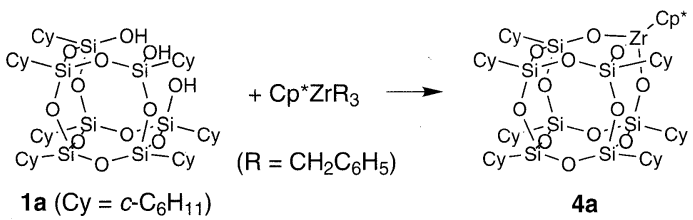

これら金属含有シルセスキオキサンは有機溶媒に可溶 であることから，均一系触媒としての機能が期待でき る。初期の研究は, アルケンの重合反応に有効な触媒の 開発から始まった。FeherらはV 種および $\mathrm{Al}$ 種を含有 するシルセスキオキサンがエチレンの重合反応に7)， Mo 含有分子がアルケンのメ夕セシス反応に ${ }^{8)}$ それぞれ 触媒活性を示すことを見出した。

1990 年代後半になって，いくつかの前周期遷移金属 種を含有するシルセスキオキサンについて，酸化触媒と しての機能が検討されている。筆者らはV 含有シルセス キオキサンのシクロペンチル誘導体 5 について, アルカ ンの光酸化反応に対する触媒活性を見出し，1997年に 報告した ${ }^{9)}$ 。シクロヘキサンの光酸化反応に対して，5 は $\mathrm{VO}\left({ }^{i} \mathrm{PrO}\right)_{3}$ 等の他の $\mathrm{V}$ 錯体を上回る活性を示した。 また, $\mathrm{VO}\left({ }^{i} \mathrm{PrO}\right)_{3} に 1 \mathrm{~b}$ をはじめとする不完全縮合かご 状シルセスキオキサンを加えることで触媒活性が向上し たが，これは反応系中で V-シルセスキオキサン種が形 成したためと考えられる。なお，筆者らはシリカ担持酸 化バナジウム触媒を用いるメタンからホルムアルデヒド への光酸素酸化反応を見出し, 触媒活性種として孤立し たオルトバナデート種を提案しているが10), 本結果は 5 がシリカ担持触媒の均一系モデル触媒として機能する ことを示している。

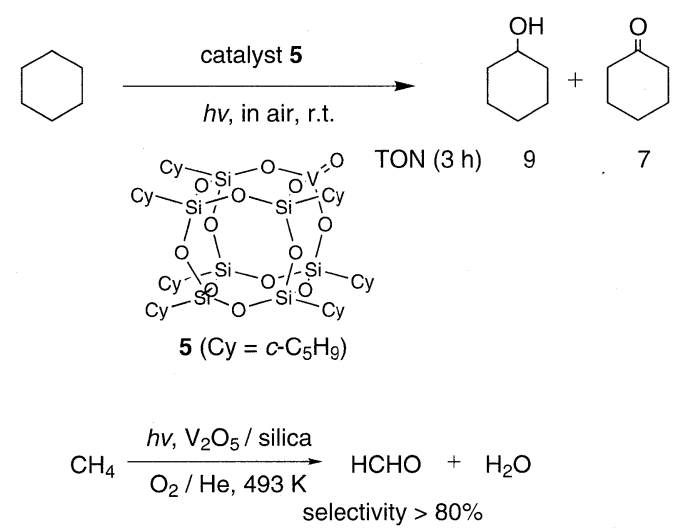


一方, Ti 含有シルセスキオキサンは, 工業的に重要 な触媒であるチタノシリケート ${ }^{11)}$ の構造に類似した分子 構造を有することから，これらの固体触媒の均一系モデ ル触媒としての観点から注目された。筆者らによるV錯 体の触媒活性の報告と同じ 1997 年に, 欧州の 3 つの独 立した研究グループは, チタン含有シルセスキオキサン が，アルケンのエポキシ化反応に対して優れた触媒活性 を有することを相次いで報告している12,13)。例えばシク ロペンタジエニル配位子を有する $6 \mathrm{a}$ は Feher らによっ て最初に合成されたが3a), Abbenhuisらはこの分子が ${ }^{t} \mathrm{BuOOH}$ を酸化劑とするシクロオクテンのエポキシ化反応 に優れた活性を有することを見出した ${ }^{12 a)}$ 。 Maschmeyer らの研究グループは 6 配位 Ti 種を含有する二量体 7 の 有効性を報告している ${ }^{12 b)}$ 。また, Crocker らはシルセ スキオキサンの構造とエポキシ化活性に関する系統的研

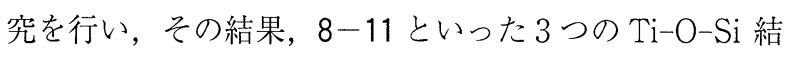
合を有し(トリポーダル)，立体障害が少ない単核分子が 最も有効であり, 単核であっても2つの $\mathrm{Ti}-\mathrm{O}-\mathrm{Si}$ 結合 を有し, Ti 周辺がやや立体的に込み合ったバイポーダ ル分子 12 や，4 つの Ti-O-Si 結合を有するテトラポー ダル二量体 13aは比較的低活性にとどまることを示し た (スキーム2) $)^{12 c)}$ 。

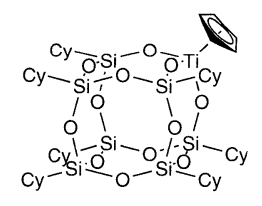

$6 \mathbf{a}\left(\mathrm{Cy}=c-\mathrm{C}_{6} \mathrm{H}_{11}\right)$

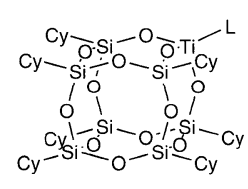

$\mathrm{L}=\mathrm{CH}_{2} \mathrm{Ph}(\mathbf{8}), \mathrm{NMe}_{2}$ (9), OTMS (10), O'Pr (11)

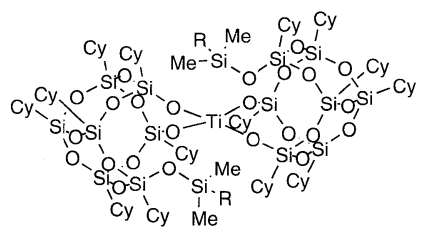

13a $(R=M e)$

13b $(R=$ vinyl $)$
$13 c(R=$ allyl $)$

Scheme 2 Titanium-containing silsesquioxanes employed for the epoxidation of alkenes.

筆者らは，14b,14c 等のアルケニルシリル基を有する シルセスキオキサンジシラノールを, 速度論的モノシリ ル化といった簡便な手法で合成できることを示し，これ らを活用して, バイポーダル型のチタノセン含有シルセ スキオキサン (15a-c) を初めて合成した ${ }^{14)}$ 。15a-c の合
成においては反応溶媒の選択が極めて重要であり，含塩 素溶媒中では全く進行しない。しかしトルエン中では ゆっくりと反応が進行し，3 日後にチ夕ノセン含有分子 が高収率で得られた。さらに，テトラポーダル型二量体 13aの誘導体 13b-c (スキーム 2 参照)を合成し, ${ }^{t} \mathrm{BuOOH}$ を酸化剂とするシクロアルケンのエポキシ化反応に対す る触媒活性を検討した(表 1)。先の Crocker らの報告に あったように，一般にバイポーダル型扰よびテトラポー ダル型シルセスキオキサンの触媒活性は決して高くな い。しかし，テトラポーダル型の場合にはアルケニルシ リル基の導入によって触媒活性の向上が認められた ${ }^{14)}$ 。 こうした現象が起こる原因については現在も検討中であ るが，これまでに系中でアルケニルシリル基のエポキシ 化が進行し, さらに一部が開環し, 重合した構造に変化 していることが判明している。極めて疎水性の高いシル セスキオキサン触媒に極性の高い部位を導入することに よって，Ti サイトへの酸化剤の配位が促進されたもの と考えられる。

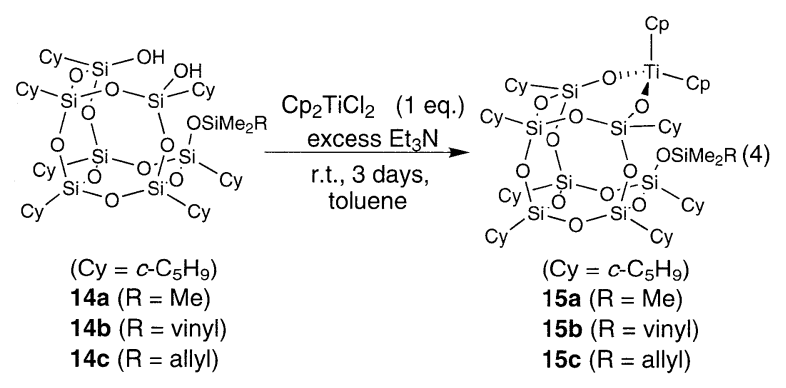

Table 1 Epoxidation of cyclooctene by ${ }^{t} \mathrm{BuOOH}$ at $50^{\circ} \mathrm{C}$ in the presence of Ti-silsesquioxane ${ }^{\mathrm{a}}$.

\begin{tabular}{cc}
\hline Catalyst & Yield of epoxide $(\%)$ \\
\hline 13a & 37 \\
13b & 60 \\
13c & 59 \\
& \\
15a & 36 \\
15b & 45 \\
15c & 35 \\
\hline${ }^{a}$ Catalyst 1.0 mol\%, alkenes $(3.3 \mathrm{mmol})$ in toluene $(1.5$
\end{tabular}
$\left.\mathrm{cm}^{3}\right)$, 'BuOOH $(3.3 \mathrm{mmol})$ in decane $\left(0.6 \mathrm{~cm}^{3}\right), 4 \mathrm{~h}$.

しかしながら，チタン含有シルセスキオキサンを通常 の均一系触媒として用いた場合の最大の問題点は, 適用 できる酸化剂が有機過酸化物に限定されることである。 筆者らもいくつかのチタン含有分子について過酸化水素 水を用いたエポキシ化反応を検討したが，全く活性を示 さなかった。しかし，次節に示すように，最近になって 過酸化水素水が適用可能なシルセスキオキサン含有触媒 がいくつか見出されていることは興味深い。

ところで, チタン含有メ夕ロセン触媒は, アルケンの 重合触媒として重要な地位を占めている ${ }^{15)}$ 。さらに, Duchateau らは Zr 含有シルセスキオキサンが重合触媒 
として機能すること示した ${ }^{3 \mathrm{f})}$ 。また最近，シリカーアル ミナ担持ジルコニウム触媒による温和な条件下でのポリ オレフィンの水素化分解反応が報告され, 触媒活性点構 造としてシリルヒドリド種に隣接したジルコニウムヒド リド種が提案されている ${ }^{16)}$ 。そこで筆者らは, 種々の置 換基を隣接して併せ持つ $\mathrm{Zr}$ および $\mathrm{Hf}$ 含有シルセスキ オキサンを合成した ${ }^{14,17)}$ 。他の材料との複合化や不均一 系触媒, ポリマー触媒への変換の手がかりとなる有用な 置換基であるアルケニルシリル基を有する分子 $(16 \mathrm{~b}-$ 18c）は，15a-c と同様の手法によって容易に合成でき る。しかし速度論的なモノシリル化では, 14d といった 置換基を有するジシラノールを選択的に得られなかっ た。そこでまず，シラノール基を 3 つ有する不完全縮合 シルセスキオキサンとジルコノセンジクロリドとの反応 後, 溶媒を変えて順次分別することにより, ジルコノセ ン含有シルセスキオキサンモノシラノール16fを合成し た。この $16 f$ あるいは $18 f$ を経由することで, シリルヒ ドリド基やゲルミル基を有する 16d, 16e, 18d を容易に 得ることができる。さらに，16d を塩化水素で処理する ことによって, 量論量のジルコノセンジクロリドに加え て，シルセスキオキサンジシラノール 14d が得られた。

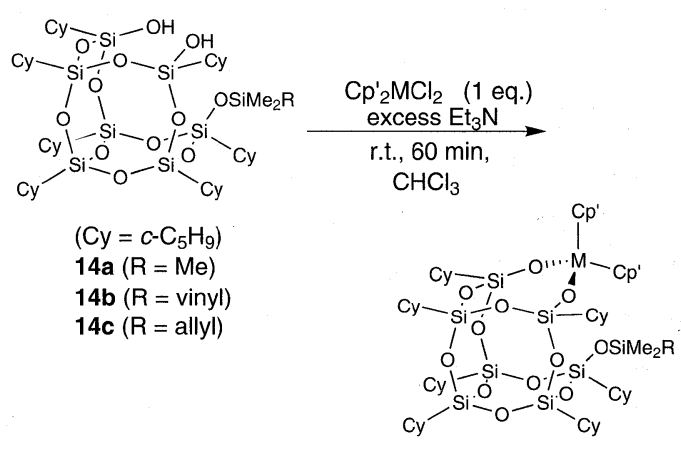

$\left(\mathrm{Cy}=\mathrm{c}-\mathrm{C}_{5} \mathrm{H}_{9}\right)$

16a $\left(\mathrm{M}=\mathrm{Zr}, \mathrm{Cp}^{\prime}=\mathrm{Cp}, \mathrm{R}=\mathrm{Me}\right)$

$16 b\left(M=Z r, C p^{\prime}=C p, R=\right.$ vinyl)

$16 c\left(M=Z r, C p^{\prime}=C p, R=\right.$ allyl $)$

17c $\left(\mathrm{M}=\mathrm{Zr}, \mathrm{Cp}^{\prime}=\mathrm{Cp}^{*}, \mathrm{R}=\right.$ allyl $)$

$18 \mathrm{c}\left(\mathrm{M}=\mathrm{l}\right.$ If, $C p^{\prime}=\mathrm{Cp}, \mathrm{R}=$ allyl)
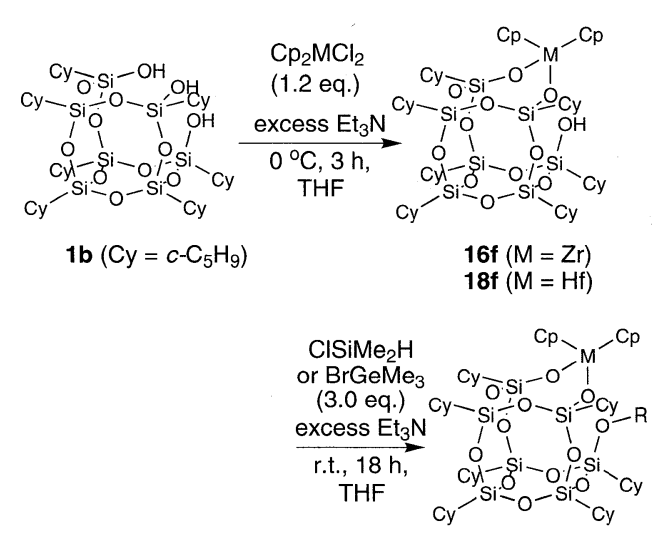

16d $\left(M=Z r, R=S i(H) M e_{2}\right)$ $16 \mathrm{e}\left(\mathrm{M}=\mathrm{Zr}, \mathrm{R}=\mathrm{GeMe}_{3}\right)$

18d $\left(M=H f, R=S i(H) \mathrm{Me}_{2}\right)$

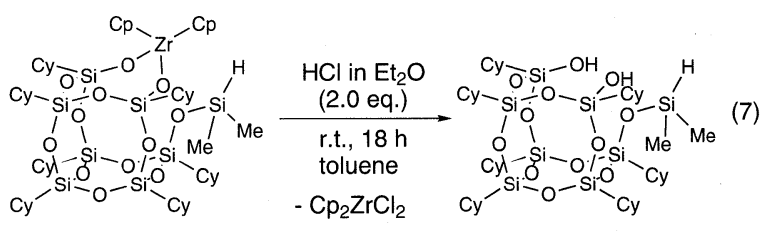

16d $\left(\mathrm{Cy}=c-\mathrm{C}_{5} \mathrm{H}_{9}\right)$

14d (>95\%)

すなわち, ジルコノセン部位をジシラノール基の保護基 として活用できることを示した。

上に示した 4 族遷移金属をはじめ, 前周期遷移金属や 典型元素を含有するシルセスキオキサンの合成は比較的 容易である。その一方で, 酸素親和性の低い後周期遷移 金属種を含む分子の合成は決して容易ではない。これま で，限られた種類の Fe や Os, Pt 等を含むシルセスキオ キサンが合成されるにとどまっている ${ }^{3 \mathrm{a}, 3 \mathrm{~g})}$ 。そこで筆 者らは，3つのリン配位部位を有するシルセスキオキサ ン 19 を新たに合成した ${ }^{18)}$ 。さらに, Ru 錯体や $\mathrm{Rh}$ 錯体

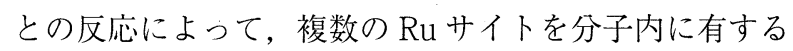
錯体 20 や, Wilkinson 錯体型の配位構造を有し, 大き

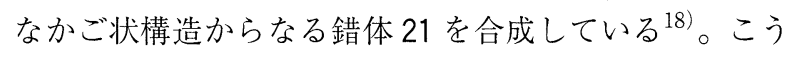
したシルセスキオキサン配位子はその立体的なかさ高さ に加えて，有機溶媒に対する高い親和性を有しており， 例えば高い溶解性を有する金属錯体触媒の合成や，金属 ナノクラスター触媒の保護配位子としての用途が考えら れる。
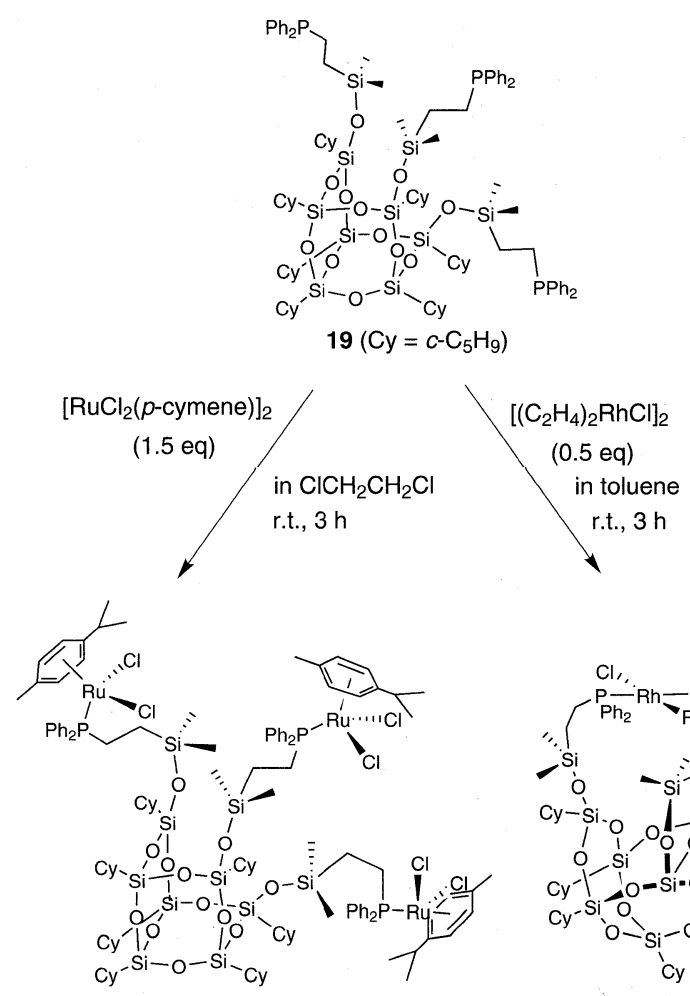

20

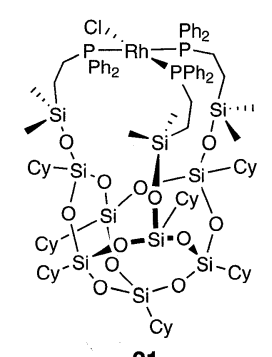

21

Scheme 3 Preparation of Ru and Rh complexes utilizing a silsesquioxane-containing phosphine ligand. 


\section{2. 多様な形態のシルセスキオキサンの合成}

金属種に加えてアルケニルシリル基等を併せ持つかご 状シルセスキオキサンについて，こうした置換基の変換 反応を適用することによって，金属種周辺の構造を保持 したまま，様々な形態へ変換することができる。チタン 含有シルセスキオキサン 13b, 13c とオクタキス(ヒドリ ドシルセスキオキサン) 22 を, 白金触媒を用いたヒドロ シリル化反応により複合化させることによって， $M_{\mathrm{w}}=$ 45000-63000 程度の可溶性ポリマー23b, 23c を得た ${ }^{19)}$ 。 紫外可視吸収スペクトル測定および ${ }^{29} \mathrm{Si}$ NMRによっ て，13b，13cに見られた $\mathrm{Ti}$ 周辺の部分構造が，ポリ マー中でもそのまま保持されていることが判明してい る。Abbenhuisらは同様の手法に基づき, チタン含有シ ルセスキオキサンとポリジメチルシロキサンを複合化さ せた有機・無機ハイブリッド材料を調製し，これが不均 一系触媒として過酸化水素水によるアルケンのエポキシ 化反応に，ある程度活性を有することを示した ${ }^{20)}$ 。筆者 らも, 上記のハイブリッドポリマー触媒によるエポキシ 化反応に過酸化水素水が適用可能であることを確認して おり, 均一系触媒としてチタン含有シルセスキオキサン を用いた場合とは対照的な結果が示されている21)。均一 系触媒とポリマー触媒で適用できる酸化剤に差異が出る 原因については不明な点が多いが, 単に触媒活性点の ローカルな構造のみではなく, 活性点周辺のナノレベル での立体的，電子的あるいは疎水的・親水的環境(ナ) 環境, nano-environment)が, 触媒活性を決定する重要
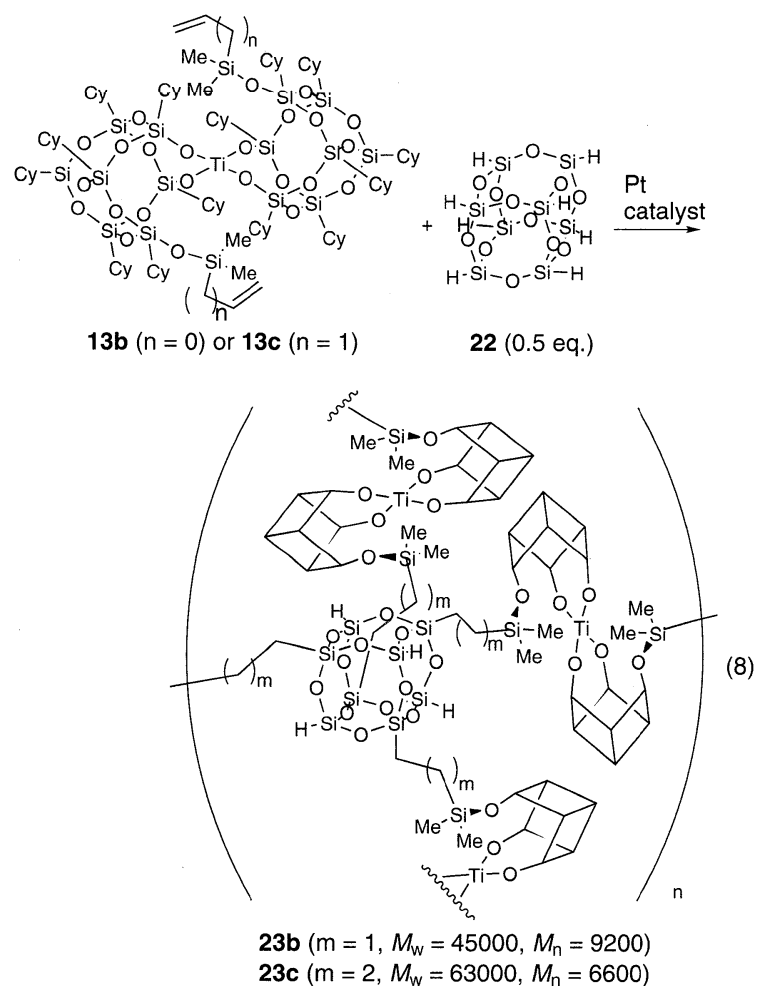

な要素であることを示唆する点で興味深い。

十分な大きさを持つスターバースト型ポリマーおよび デンドリマーは，ナノフィルトレーションによって分 離・回収が可能であるが，これらを活用すれば，均一系 触媒としての機能を保持しながら回収・再利用が可能な 触媒材料の開発につながる可能性があり，近年特に注目 されている22)。24のような，かご状シルセスキオキサ ンはデンドリマー等のコアとしてしばしば用いられる が，筆者らは白金触媒によるヒドロシリル化反応を用い て，コアのみでなく，周辺部位もかご状シルセスキオキ サンで構成されたスターバースト型巨大分子 25 を合成

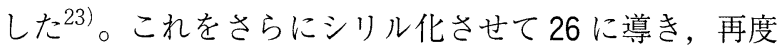
ヒドロシリル化反応を適用するダイバージェント法に よって，32 個のシラノール基を有する第二世代デンド リマー 27 を合成した。また，25にフェニルジクロロボ ランを作用させて， 8 個のホウ素を含む分子 28 に導く こともできる。中でも 27 は，若干の欠陥を含むものの， ナノフィルトレーションによって分離できる十分な大き さを有しており，触媒担体としての機能が期待できる。

一方，分子内に 2 つ以上のアリル基を有するシルセス キオキサンの閉環反応によって，大きな環状構造が構築 できる。例えば，チタン含有シルセスキオキサン 13c の アリル部位の分子内メタセシス反応によって，ねじれた 21 員環が形成された 29 が得られる24a)。さらに，アル キニルシリル基を 3 つ有するシルセスキオキサン 30 の, Co 錯体触媒を用いる分子内環化三量化反応を検討し, ちょうどベンゼン環でふたをしたような構造の有機・無 機複合かご状骨格を有する新規シルセスキオキサンの異 性体混合物 (1, 3, 5-体 31a, 1, 2, 4-体 31b) が得られるこ とを見山した。これらはカテムクロマトグラフィーで分 離・精製可能である。このような，大きな環状あるいは かご状骨格を有する分子の合成は, 新規機能性材料のた めのモノマーとしての用途に加えて, ゼオライト等の 「細孔構造」のモデルとしても極めて興味深い24b)。
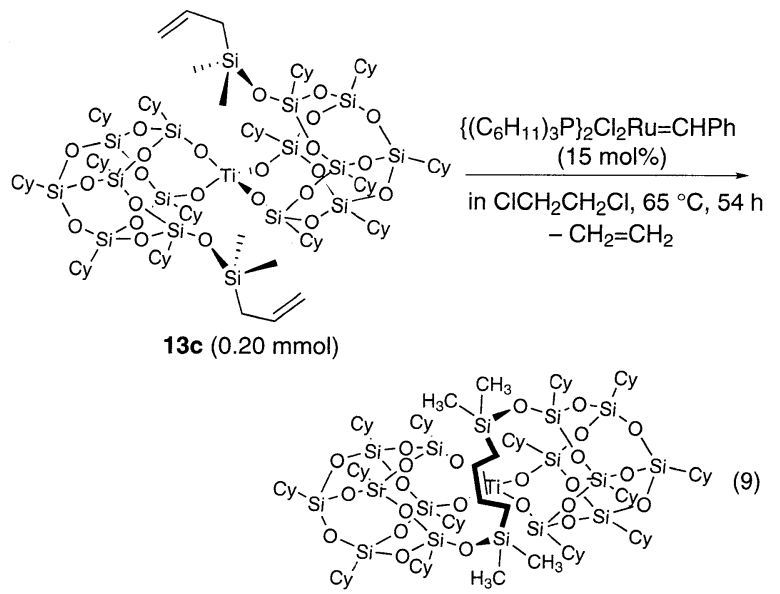

$29(74 \%, Z: E=4.4: 1)$ 


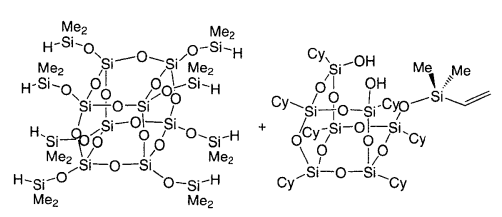

24

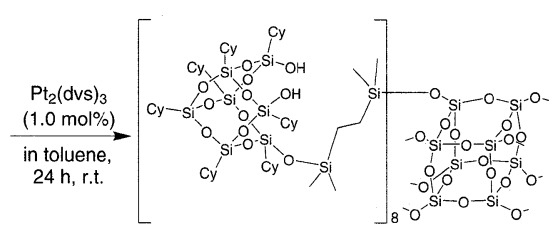

$25(83 \%)$

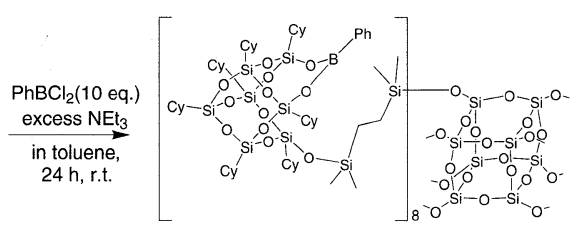

$28(53 \%)$

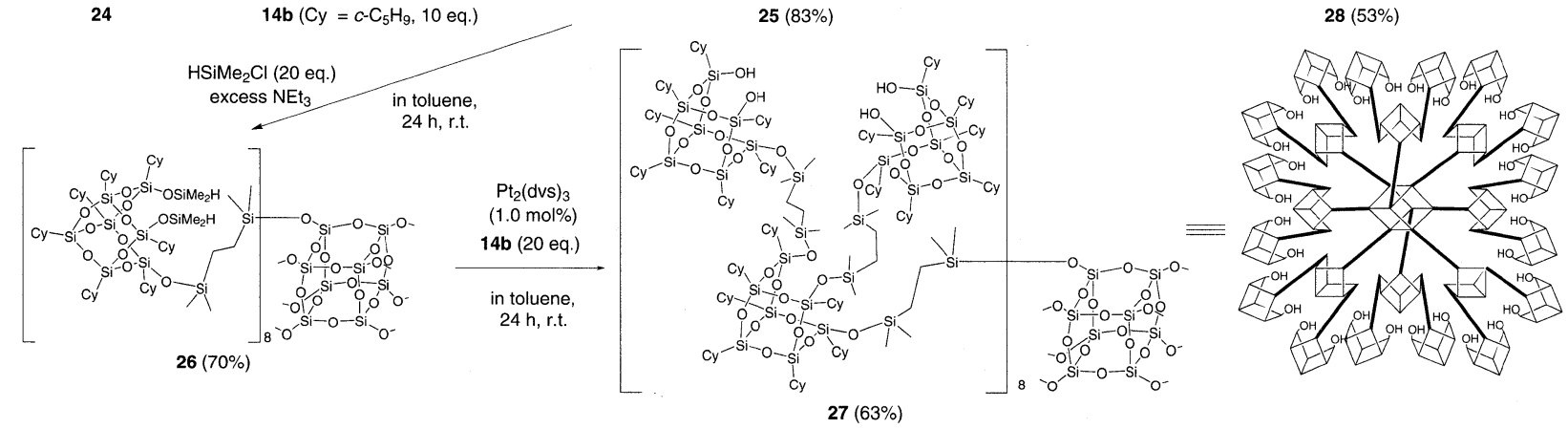

Scheme 4 Preparation of starburst and dendritic silsesquioxanes.
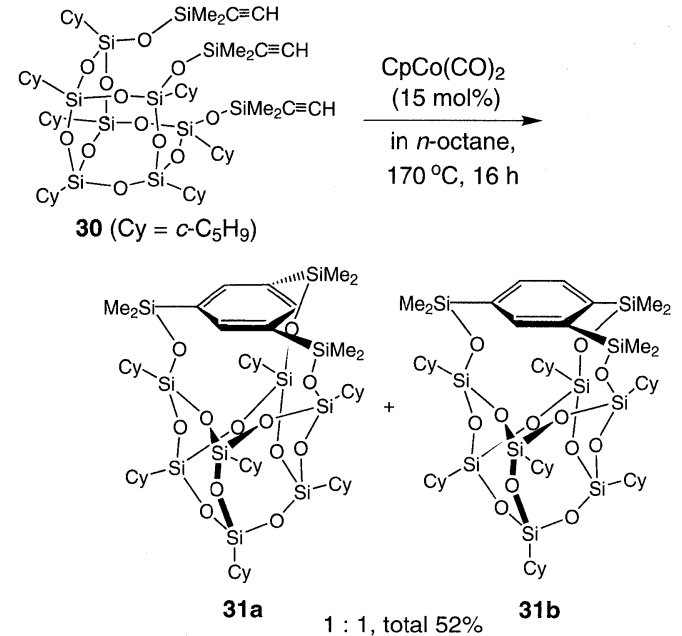

\section{3. シルセスキオキサンを活用した特異的細孔構造を} 有する多孔質酸化物の調製と触媒機能

金属含有シルセスキオキサンの M-O-Si 結合を保持 したまま酸化物に変換できれば，極めて分散性の高い金 属種を含有するシリカ触媒が得られるものと期待でき る。そこで筆者らは, チタン含有シルセスキオキサン $6 b$ を乾燥空気気流中で注意深く焼成したところ, 焼成 温度を $723 \mathrm{~K}-823 \mathrm{~K}$ とした場合に $350-500 \mathrm{~m}^{2} \mathrm{~g}^{-1}$ と大 きな比表面積を有する多孔質酸化物が得られた。特に, 非晶質であるにもかかわらず，その細孔直径が $0.6 \mathrm{~nm}$ 程度に均一に制御されていることが極めて特徽的であ る。焼成温度を $823 \mathrm{~K}$ 以上に上げると比表面積が大き く低下し, $723 \mathrm{~K}$ 以下では酸化物表面への炭素質の蓄積 が認められた。これらの酸化物を XPS $(\mathrm{X}$ 線光電子分 光)によって分析したところ, Ti $2 \mathrm{p}$ 電子の結合エネル ギーが，通常の酸化チタンの值よりも高エネルギー側に シフトしており, 電子求引性を有するシロキサン骨格中 に孤立した高分散 $\mathrm{Ti}^{4+}$ 種が存在していることが示され

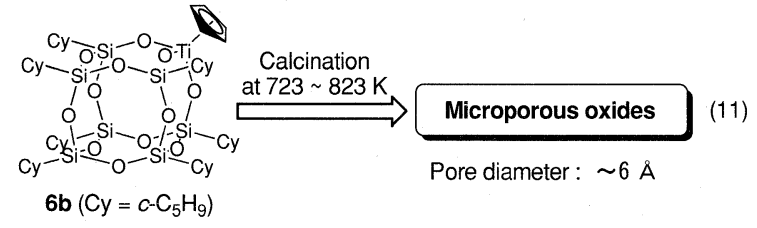

$た^{25)}$ 。

重質油等の付加価值の低い炭素資源を，接触分解に よってょり有用な留分に高効率的に変換するためには, ゼオライトに匹敵する強い Brönsted 酸点を豊富に有 し，かつ大きな炭素資源分子を収容できる細孔を有する 触媒の開発が欠かせない26)。このような目的から, $\mathrm{Al}$ 種等を導入したメソポーラスアルミノシリケート触媒の 開発等が進められているが，非晶質である場合には十分 な強度の Brönsted 酸性を発現させることは容易ではな い。そこで筆者らは，Al 種周辺に 4 つの Al-O-Si 結合 を有するテトラポーダル $\mathrm{Al}$ 含有シルセスキオキサンを 合成し,これらの Al-O-Si 結合を保持l，たま酸化物 に変換できれば，十分な強度の Brönsted 酸点を構築で

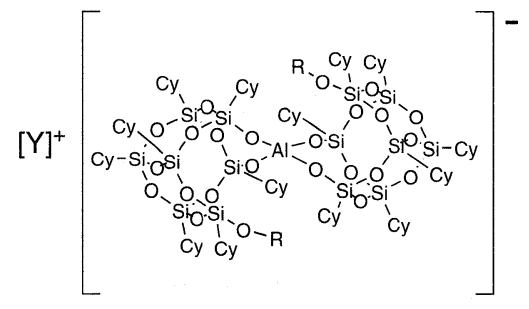

$\left(\mathrm{Cy}=\mathrm{C}-\mathrm{C}_{5} \mathrm{H}_{9}\right)$

32a $\left(\mathrm{R}=\mathrm{SiMe}_{3}, \mathrm{Y}=\mathrm{HNEt}_{3}\right)$

32b $\left(\mathrm{R}=\mathrm{SiMe}_{3}, \mathrm{Y}=\mathrm{H}_{2} \mathrm{NEt}_{2}\right)$

32c $\left(\mathrm{R}=\mathrm{SiMe}_{3}, Y=\mathrm{HNMe}_{2}(\right.$ n-octyl) $)$

32d $\left(\mathrm{R}=\mathrm{SiMe}_{3}, \mathrm{Y}=\mathrm{HC}_{5} \mathrm{H}_{5} \mathrm{~N}\right)$

32e $\left(\mathrm{R}=\mathrm{SiMe}_{3}, \mathrm{Y}=\mathrm{HNMe}_{2}(n\right.$-octadecyl $\left.)\right)$

$32 f\left(R=\mathrm{SiMe}_{2}\right.$ (allyl), $\left.Y=\mathrm{HNC}_{5} \mathrm{H}_{5}\right)$

Scheme 5 Al-bridged silsesquioxanes used for the preparation of solid acidic oxide catalysts. 
きると考え，検討を行った27)。

まず，対カチオンの異なる種々の新規 $27 \mathrm{a}, \mathrm{b})$ 抢よび既 報 ${ }^{28)}$ の $\mathrm{Al}$ 架橋シルセスキオキサン $(32 \mathrm{a}-32 \mathrm{e})$ を合成し た。これらは, ゼオライト中の Brönsted 酸性を示す $\mathrm{Al}$ 種について, これまで提起されている想定構造と極めて 類似した構造を有していることが特徽的である27b,28)。

$\mathrm{Al}$ 含有シルセスキオキサンを $823 \mathrm{~K}$ 付近で注意媣く 焼成することによって，460-520 $\mathrm{m}^{2} \mathrm{~g}^{-1}$ と大きな比表 面積を有する非晶質の多孔質アルミノシリケートを調製 した。得られた酸化物を以後, 前駆体化合物番号と焼成 温度 $(\mathrm{K})$ を併せて，32a-823のように表記する。サイズ が異なる種々の対カチオンを有する $\mathrm{Al}$ 含有シルセスキ オキサンを前駆体として検討したが，細孔直径はいずれ も 0.5-0.6 nmであり, 対カチオンの影響をほとんど受 けない。XPSによる分析結果から, Ti 含有シルセスキ オキサンの場合と同様に，シロキサン骨格中に孤立した $\mathrm{Al}^{3+}$ 種が存在していることが示された。また，アンモニ ア TPD (昇温脱離) 法を用い, $\mathrm{Al}$ 含有シルセスキオキサ ンの焼成によって得た酸化物表面を評価したところ，市 販の非晶質アルミノシリケートよりも強く, 代表的なゼ オライト触媒である HZSM-5 をやや下回る強度の固体 酸性を示すことが判明した。さらにピリジンを吸着後の FTIR 分析の結果, 表面酸点の大部分が Brönsted 酸点 であることが示された。

これらの酸化物触媒の接触分解反応に対する活性を評 価するため，常圧パルス型反応装置を用いて，代表的な プローブ反応であるクメンの分解反応を検討した。図 1 に結果を示したが，反応温度 $673 \mathrm{~K}$ においては， $\mathrm{Al}$ 含 有シルセスキオキサンを前駆体とする触媒は, 転化率が ほほ 100\%に達し，HZSM-5 ゼオライトに匹敵する高活 性が認められた。市販の非晶質アルミノシリケート (CICC-LA) では転化率 $65 \%$ 程度にとどまった。一方， 反応温度 $523 \mathrm{~K}$ と大きく下げた場合, 非晶質アルミノ シリケートが全く活性を示さなかったのに対して，Al 含有シルセスキオキサン由来の触媒は, HZSM-5 ゼオ
ライトをやや下回るものの，優れた活性を示した。な 拉，B 拉よび $\mathrm{Ga}$ を含有するシルセスキオキサンからも 多孔質固体酸触媒を調製したが， $\mathrm{Al}$ 種を含むものに比

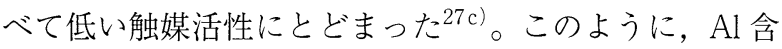
有シルセスキオキサンを前駆体とすることで，非晶質酸 化物としては例外的に高いクメン分解活性を示寸固体酸 触媒が得られることが明らかになった。

ところで，こうしたシルセスキオキサンは有機溶媒に 可溶であることから，含浸担持等によって他のメソおよ びマクロポーラス材料と組み合わせて焼成すれば，メソ あるいはマク口細孔内壁にミク口細孔を構築できる可能 性がある。先に述べたように，メタンのホルムアルデヒ ドへの選択的光酸化反応に有効なシリカ担持酸化バナジ ウム触媒の調製においては，極めて高分散でお互いに孤 立した $\mathrm{O}=\mathrm{V}(\mathrm{OSi})_{3}$ 種の触媒表面への構築が重要であ る ${ }^{10)}$ 。そこで，本反応に扔ける触媒活性点に類似した構 造を有するバナジウム含有シルセスキオキサン 5 を活用 した触媒調製を検討した ${ }^{29)}$ 。その結果，5をシリカに含 浸担持後, 乾燥空気気流中で $723 \mathrm{~K}$ で焼成した触媒が, メタンの選択的光酸化反応に極めて高い活性を示すこと が判明した(表 2)。この担持酸化バナジウム触媒は, メ タバナジン酸アンモニウムのシュウ酸水溶液から通常の 含浸法で調製した触媒の 2 倍以上の活性を示す。また, 担体のシリカ $\left(259 \mathrm{~m}^{2} \mathrm{~g}^{-1}\right)$ を上まわる比表面積 (349 $\left.\mathrm{m}^{2} \mathrm{~g}^{-1}\right)$ を有しており，V含有シルセスキオキサンに由来 するミクロ細孔に加えて、メソ細孔が新たに形成されて いた。含浸担持の際に，V種がシルセスキオキサン部位 とシリカ表面間のリンカーとして機能したものと考えら れる。また, 触媒活性の顕著な向上は, 表面積の増加 と, 極めて立体的にかさ高いシルセスキオキサン配位子 の影響による酸化バナジウム種の分散性の向上によるも のと考えられる。

なお，金属含有シルセスキオキサンの焼成による多孔 質酸化物触媒調製に関寸る筆者らの最初の報告以来，他 のいくつかの研究グループが本手法を適用して種々の金 (a)

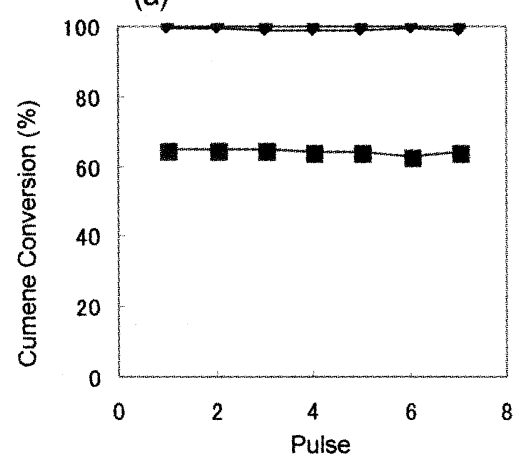

(b)

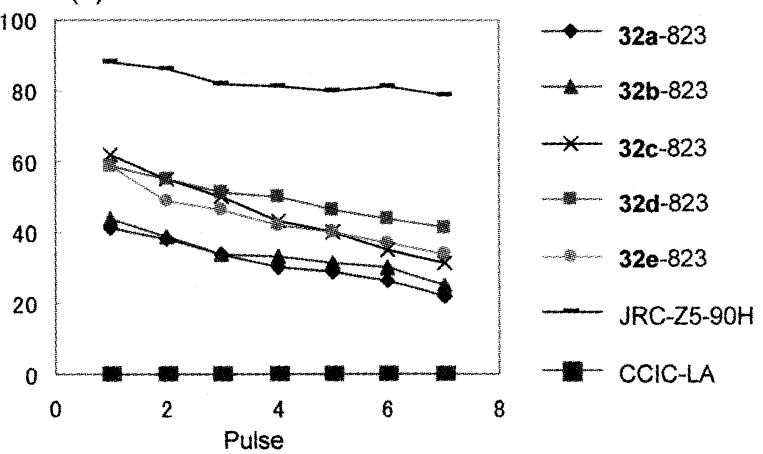

Fig. 1 Activity of silsesquioxane-based catalysts for the cracking of cumene at (a) $673 \mathrm{~K}$ and (b) $523 \mathrm{~K}$. 
Table 2 Photo-assisted partial oxidation of methane ${ }^{\mathrm{a}}$.

\begin{tabular}{|c|c|c|c|}
\hline \multirow{2}{*}{ Catalyst } & \multicolumn{2}{|c|}{ Yield $\left(\mu \mathrm{mol} \mathrm{h}{ }^{-1}\right)$} & \multirow[b]{2}{*}{$\mathrm{CO}_{2}$} \\
\hline & $\mathrm{HCHO}$ & $\mathrm{CO}$ & \\
\hline none & 0 & 0 & 0 \\
\hline 5 / silica (dried) ${ }^{b}$ & 7 & 9 & 18 \\
\hline 5 / silica (calcined) ${ }^{b}$ & 139 & 26 & 6 \\
\hline $\mathrm{V}_{2} \mathrm{O}_{5} /$ silica ${ }^{\mathrm{c}}$ & 61 & 13 & 7 \\
\hline
\end{tabular}

aCatalyst $50 \mathrm{mg}, 493 \mathrm{~K}, 1 \mathrm{~h}$, using a high power $200 \mathrm{~W}$ Hg-lamp. bV 1.9 mol\%. ${ }^{\mathrm{C} V} 2.0 \mathrm{~mol} \%$

属種を有する酸化物触媒を調製し，主に酸化反応に対す る触媒活性が検討されており ${ }^{30)}$, 多孔質酸化物の調製法 として本手法は一般性を有するものと考えられる。

\section{おわりに}

かご状シルセスキオキサンは, 当初は固体触媒のモデ ル化合物としての観点から注目されたが, 近年の顕著な この分野の研究の進展によって，モデル分子の枠を超え た触媒機能の開発が期待されるようになった。特に高性 能触媒の開発のためには，単に触媒活性点の厳密制御の みにとどまらず，触媒材料全体を総合的にデザインし， 制御して構築していく必要があるが，シルセスキオキサ ンを構成ユニットとすることで, こうした材料がより容 易に構築できるものと考えられる。本稿の前半では, 均 一系触媒としての機能, 特に活性点周辺のナノ環境の重 要性を示す結果を紹介し, さらに, 反応性置換基の導入 と, これらを活用した大きなかご状構造やポリマー材 料，デンドリマー等の材料合成について述べたが，こう した成果は, ナノレベルでの立体的, 電子的あるいは疎 水的・親水的環境, すなわちナノ環境を自在に制御でき る触媒材料創製につながるものである。

また，後半では，金属含有シルセスキオキサンを前駆 体とすることで, 他の手法では達成困難な特異的なミク 口細孔構造を有する酸化物触媒材料が得られることを示 した。特にシルセスキオキサンは有機溶媒に可溶である ことから，含浸・焼成することで様々な材料の表面に， 容易に触媒機能を有するミクロポーラスシリカを構築で きるという特徴がある。こうした手法は，従来のゼオラ イト合成法やゾルゲル法等とは異なる, 全く新しい方法 論によるミクロ制御構造体の調製法を提供するものとし て興味深い。

なお, 本研究の一部は文部科学省科学研究費補助金, 京都大学 21 世紀 COE プログラム「学域統合による新材 料科学の研究拠点」, および財団法人池谷科学技術振興 財団の支援を受けて実施したものであり，感謝いたしま 宁。

(2006 年 3 月 3 日受理)

\section{文 献}

1) K. Weissermel, H. J. Arpe, "Industrial Organic Chemistry," 4 th ed, VCH, Weinheim, 2003

2）かご状シルセスキオキサンに関する総説: (a) R. H. Baney, M. Itoh, A. Sakakibara, T. Suzuki, Chem. Rev., 95, 1409 (1995); (b) P. G. Harrison, J. Organomet. Chem., 542, 141 (1997)

3）金属含有シルセスキオキサンに関する総説：(a) F. J. Feher, T. A. Budzichowski, Polyhedron, 14, 3239 (1995); (b) R. Murugavel, A. Voigt, M. G. Walawalkar, H. W. Roesky, Chem. Rev., 96, 2205 (1996); (c) H. C. L. Abbenhuis, Chem. Eur. J., 6, 25 (2000); (d) T. Mitsudo, K. Wada, Shokubai, 42, 282 (2000); (e) V. Lorenz, A. Fischer, S. Giessmann, J. W. Gilje, Y. Gun'ko, K. Jacob, F. T. Edelmann, Coord. Chem. Rev., 206-207, 321 (2000); (f) R. Duchateau, Chem. Rev., 102, 3525 (2002); (g) R. W. J. M. Hanssen, R. A. van Santen, H. C. L. Abbenhuis, Eur. J. Inorg. Chem., 675 (2004); (h) K. Wada, T. Mitsudo, Catal. Surveys Asia, 9, 229 (2005)

4) J. F. Brown, L. H. Vogt, J. Am. Chem. Soc., 87, 4313 (1965)

5) F. J. Feher, J. Am. Chem. Soc., 108, 3805 (1986)

6) F. J. Feher, T. A. Budzichowski, R. L. Blanski, K. J. Weller, J. W. Ziller, Organometallics, 10, 526 (1991)

7) F. J. Feher, J. F. Walzer, R. L. Blanski, J. Am. Chem. Soc., $113,3618(1991)$

8) F. J. Feher, T. L. Tajima, J. Am. Chem. Soc., 116, 2145 (1992)

9) (a) K. Wada, M. Nakashita, A. Yamamoto, H. Wada, T. Mitsudo, Chem. Lett., 1997, 1209; (b) idem, Res. Chem. Intermed., 24, 515 (1998)

10) K. Wada, K. Yamada, Y. Watanabe, T. Mitsudo, J. Chem. Soc., Faraday Trans., 94, 1771 (1998)

11）例えば I. W. C. E. Arends, R. A. Sheldon, M. Wallau, U. Schuchardt, Angew. Chem., Int. Ed. Engl., 36, 1144 (1997)

12) (a) H. C. L. Abbenhuis, S. Krijnen, R. A. van Santen, Chem. Commun., 1997, 331; (b) T. Maschmeyer, M. C. Klunduk, C. M. Martin, D. S. Shephard, J. M. Thomas, B. F. G. Johnson, ibid., 1997, 1847; (c) M. Crocker, R. H. M. Herold, G. Orpen, ibid., 1997, 2411

13) (a) J. M. Thomas, G. Sankar, M. C. Klunduk, M. P. Attfield, T. Maschmeyer, B. F. G. Johnson, R. G. Bell, J. Phys. Chem. B, 103, 8809 (1999); (b) M. Crocker, R. H. M. Herold, G. Orpen, M. T. A. Overgaag, J. Chem. Soc., Dalton Trans., 1999, 3791; (c) B. F. G. Johnson, M. C. Klunduk, C. M. Martin, G. Sankar, S. J. Teate, J. M. Thomas, J. Organomet. Chem., 596, 221 (2000); (d) P. P. Pescarmona, J. C. van der Waal, I. E. Maxwell, T. Maschmeyer, Angew. Chem. Int. Ed., 40, 740 (2001)

14) K. Wada. N. Itavama. N. Watanabe. M. Bundo. T. Kondo. T. Mitsudo, Organometallics, 23, 5824 (2004)

15）例えば T. J. Marks, Acc. Chem. Res., 25, 57 (1992)

16) V. Dufaud, J. M. Basset, Angew. Chem. Int. Ed., 37, 806 (1998)

17) K. Wada, M. Bundo, D. Nakabayashi, N. Itayama, T. Kondo, T. Mitsudo, Chem. Lett., 2000, 628

18) K. Wada, D. Izuhara, M. Shiotsuki, T. Kondo, T. Mitsudo, Chem. Lett., 2001, 734

19) K. Wada, K. Yamada, D. Izuhara, T. Kondo, T. Mitsudo, Chem. Lett., 2000, 1332

20) M. D. Skowronska-Ptasinska, M. L. W. Vorstenbosch, R. A. van Santen, H. C. L. Abbenhuis, Angew. Chem. Int. Ed., 41, 637 (2002)

21) K. Wada, N. Watanabe, T. Mitsudo, unpublished results

22）例えば H. P. Dijkstra, G. P. M. van Klink, G. van Koten, Acc. Chem. Res., 35, 798 (2002)

23) K. Wada, N. Watanabe, K. Yamada, T. Kondo, T. Mitsudo, Chem. Commun., 2005, 95

24) (a) K. Wada, D. Izuhara, K. Yamada, M. Shiotsuki, T. Kondo, 
T. Mitsudo, Chem. Commun., 2001, 1802; (b) K. Wada, T. Yamasaki, T. Kondo, T. Mitsudo, Chem. Lett., 33, 1218 (2004)

25) K. Wada, M. Nakashita, M. Bundo, K. Ito, T. Kondo, T. Mtsudo, Chem. Lett., 1998, 659

26) J. G. Speight, "The Chemistry and Technology of Petroleum," Dekker, New York, 1991

27) (a) K. Wada, K. Yamada, T. Kondo, T. Mitsudo, J. Jpn. Petrol. Inst., 45, 15 (2002); (b) K. Wada, K. Tada, N. Itayama, T. Kondo, T. Mitsudo, J. Catal., 228, 374 (2004); (c) K. Wada, K. Yamada, T. Kondo, T. Mitsudo, Chem. Lett., 2001, 12

28) (a) F. T. Edelmann, Y. K. Gun'ko, S. Giessmann, F. Olbrich, Inorg. Chem., 38, 210 (1999); (b) R. Duchateau, R. J. Harmsen, H. C. L. Abbenhuis, R. A. van Santen, A. Meetsma, S. K. H. Thiele, M. Kranenburg, Chem. Eur. J., 5, 3130 (1999)

29) K. Wada, M. Nakashita, A. Yamamoto, T. Mitsudo, Chem. Commun., 1998, 133

30）例えば（a) N. Maxim, H. C. L. Abbenhuis, P. J. Stobbelaar, B. L. Mojet, R. A. van Santen, Phys. Chem. Chem. Phys., 1, 4473 (1999); (b) R. Murugavel, P. Davis, V. Shete, Inorg. Chem., 42, 4696 (2003)

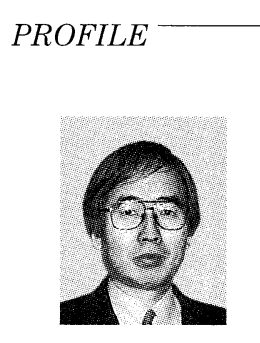

光藤武明 京都大学名誉教授

〔経歴〕1972 年京都大学大学院工学研究科燃 料化学専攻博士課程中退, 工学博士。1993 年から京都大学大学院工学研究科物質エネル ギー化学専攻教授, 2006 年から京都大学名誉 教授。〔専門〕有機金属化学, 触媒機能化学。 〔連絡先] e-mail:

和田健司 京都大学大学院工学研究科物質工 ネルギー化学専攻・講師

〔経歴〕1992 年京都大学大学院工学研究科石 油化学専攻博士課程修了, 博士 (工学)。京都 大学工学部石油化学科助手, 京都大学大学院 工学研究科物質エネルギー化学専攻助手を経 て、,2003 年から現職。[専門]触媒化学。〔連 絡先] e-mail:

\section{0 \\ 書 評 \\ 00000000.00}

\section{天然物の全合成一華麗な戦略と方法一}

竜田邦明 著

朝倉書店 A 4 判 $\cdot 256$ 頁 定価 (5,600円十税)

本書は, 我が国を代表する天然物合成化学者による, 著者自身のグループと他のグループによりこれまでに達 成された，数多の天然物全合成の紹介を骨子とした労作 である。「まえがき」と「あとがき」を除く全頁を通して， 全合成中間体の構造式，反応条件，キーワードと文献リ ストを用いて対象となる天然物全合成を紹介している本 書は，実に斬新なものである。まさしく，構造式が「化 学を語る最も簡潔な言葉」である。書評を担当するにあ たり，alphabeticalに並べられた 59 の天然物(と関連す る天然物)に関する，世界中で達成された全合成の概要 に目を通しながら，評者は久しぶりに時の経つのも忘れ て興奮し，また己の浅学さを再認識させられた。また， 合成中間体の構造とそこに至る数工程の反応条件のみを 基に，いかなる官能基変換が起ったのかを推測すること は，謎解きにも似た知的楽しみを評者に与えてくれた。 本書は，新規な有機合成法の開発が，複雑かつ新奇な構 造をもつ天然物の全合成にいかに活用されてきたか，と いう実例の showcase でもある。例えば，hirsutenes(あ るいは coriolins), また thienamycinの全合成の項では,
20 を越える全合成が紹介されている。これらの比較的 小分子の天然物合成に関しても，実に多様な合成アプ ローチが報告されていた事実を評者はあらためて知っ た。著者自身が「あとがきで述べているごとく，「実際 に本書の作成中，同一の天然物の全合成に，こんなに多 くの方法論があったのかと驚き感激した次第である」。 そしてなによりも本書から，「美」「芸術性」「華」「こだ わり」という観点から天然物全合成に挑戦し続けている 著者の「熱き思い」を，評者はあらためて感じとった。評 者は，著者と同時代に同じ分野での研究に従事している 幸せを感じている。これからも，有機合成化学は天然物 合成化学へ「革新的な合成法」を提供する分野であって欲 しいと思う。その意味でも，有機合成に関わる産官学の 研究者諸氏，そして学生諸君が本書を手元におき，天然 物合成と自らの研究の関わりをたえず意識して欲しいと 願う。最後に評者は，類いまれなる著作として本書を高 く評価し，推薦申し上げる次第である。

(只野金一) 